\title{
CORRELATION OF PORTAL VEIN DIAMETER AND SPLENIC SIZE WITH OESOPHAGEAL VARICES IN CIRRHOSIS OF LIVER
} \author{
Pravat Kumar Thatoi ${ }^{8}$ \\ ${ }^{1}$ Associate Professor, Department of Medicine, SCB Medical College, Cuttack. \\ ${ }^{2}$ Associate Professor, Department of Medicine, SCB Medical College, Cuttack. \\ ${ }^{3}$ Postgraduate Student, Department of Medicine, SCB Medical College, Cuttack. \\ ${ }^{4}$ Senior Resident, Department of Medicine, SCB Medical College, Cuttack. \\ ${ }^{5}$ Postgraduate Student, Department of Medicine, SCB Medical College, Cuttack. \\ ${ }^{6}$ Postgraduate Student, Department of Medicine, SCB Medical College, Cuttack. \\ ${ }^{7}$ Postgraduate Student, Department of Medicine, SCB Medical College, Cuttack. \\ ${ }^{8}$ Assistant Professor, Department of Medicine, SCB Medical College, Cuttack.
}

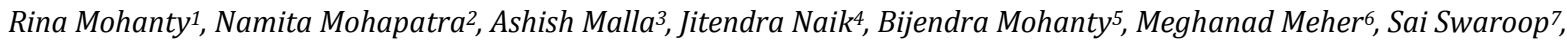

\section{ABSTRACT}

\section{BACKGROUND}

Portal hypertension is one of the serious complications of cirrhosis of liver leading to unwanted life-threatening variceal bleeding. Loss of liver architecture and fibrosis lead to increased resistance to blood flow through portal vein causing portal hypertension and ultimately leading to ascites, oesophageal varices and splenomegaly.

The aim of the study is to find out correlation of portal vein diameter and splenic size with oesophageal varices in cirrhosis of liver.

\section{MATERIALS AND METHODS}

A descriptive study was conducted in Department of Medicine of SCB Medical College, Cuttack and consecutively 50 adult patients of cirrhosis of liver were included in the study. Ultrasonography was done in all patients to measure splenic size and portal vein diameter. Upper GI endoscopy was done in all to record oesophageal varices.

\section{RESULTS}

Out of 50 patients, $34(68 \%)$ had oesophageal varices of various grades and $16(32 \%)$ had no varices. Average portal vein diameter of patients with oesophageal varices was $13.46 \pm 0.98 \mathrm{~mm}$ and that of patients without varices was $10.91 \pm 0.65 \mathrm{~mm}(\mathrm{p}=0.03$ ). Average splenic size in patients with oesophageal varices was $14.7 \pm 0.82 \mathrm{~cm}$ and that of patients without varices was $12.2 \pm 1.01$ $\mathrm{cm}(\mathrm{p}=0.007)$. Portal vein diameter and splenic size were increased in patients with oesophageal varices than patients without varices.

\section{CONCLUSION}

In our study, we found definite correlation between increase in splenic size and portal vein diameter with severity of oesophageal varices.

\section{KEYWORDS}

Cirrhosis of Liver, Oesophageal Varices, Portal Hypertension.

HOW TO CITE THIS ARTICLE: Mohanty R, Mohapatra N, Malla A, et al. Correlation of portal vein diameter and splenic size with oesophageal varices in cirrhosis of liver. J. Evolution Med. Dent. Sci. 2017;6(82):5746-5749, DOI: 10.14260/jemds/2017/1246

\section{BACKGROUND}

Portal hypertension is one of the serious complications of cirrhosis of liver leading to unwanted life-threatening variceal bleeding. It is defined as elevation of hepatic venous pressure gradient more than $5 \mathrm{mmHg}$ and is caused by increased intrahepatic resistance to blood flow due to loss of liver architecture in cirrhosis which ultimately leads to splenomegaly, ascites and oesophageal varices. Dib et $\mathrm{al}^{1}$ showed oesophageal varices were developed when portal vein diameter exceeds $13 \mathrm{~mm}$. Mandal et $\mathrm{al}^{2}$ found a positive correlation between increase in portal vein diameter and

'Financial or Other Competing Interest': None.

Submission 01-09-2017, Peer Review 02-10-2017,

Acceptance 07-10-2017, Published 12-10-2017.

Corresponding Author:

Pravat Kumar Thatoi,

Flat-104, Aryabhatta Complex,

College Square, Cuttack-753003,

Odisha, India.

E-mail: drsajinidileep@yahoo.co.in

DOI: $10.14260 / \mathrm{jemds} / 2017 / 1246$ which need upper gastrointestinal (GI) endoscopy for detection. But upper GI endoscopy is not available in all centres and is also a painful invasive procedure whereas ultrasonography is easily available noninvasive method. It can measure portal vein diameter and splenic size and also can predict which patients benefit most from endoscopic screening of oesophageal varices in cirrhosis of liver. We, therefore, designed a study to find out correlation between portal vein diameter and splenic size with development of gastro-oesophageal varices.

\section{MATERIALS AND METHODS}

This study was a descriptive study. After clearance from institutional ethics committee, we included consecutively 50 adult patients of cirrhosis of liver. Written consent was obtained from each individual participating in the study.

\section{Patient Selection Criteria}

Newly or previously diagnosed patients of cirrhosis were included based on their clinical, biochemical and ultrasonographic findings. 


\section{Exclusion Criteria}

Patients with gastrointestinal bleed, encephalopathy or on treatment for portal hypertension (pharmacological, variceal ligation, sclerotherapy or shunt surgery) and other causes of portal hypertension i.e. non-cirrhotic portal fibrosis, BuddChiari syndrome, extrahepatic portal vein obstruction were excluded.

\section{Methods}

The selected patients were admitted to Department of Medicine of SCB Medical College, Cuttack. Detailed history was taken including occupation, alcohol intake, appetite, jaundice and unconsciousness. These patients were thoroughly examined for size of spleen, liver span, presence of ascites, palmar erythema, loss of axillary hair, venous prominence, gynaecomastia and testicular atrophy (in males). Investigations like complete blood counts (CBC), liver function tests (LFTs), prothrombin time (PT), INR, HBsAg, Anti-HBC antibody, urine analysis, ultrasonography of abdomen and upper GI endoscopy were done in every patient. Patients were divided into two groups according to presence or absence of oesophageal varices as variceal group and non-variceal group accordingly.

\section{Splenic Size Measurement}

Size of the spleen was measured by using 6-12 $\mathrm{MHz}$ curvilinear transducer in the coronal plane posteriorly in supine position. The average adult spleen measures $10-11 \mathrm{~cm}$ in length and the maximum cephalocaudal measurement exceeding $13 \mathrm{~cm}$ indicates splenic enlargement. ${ }^{3}$

Portal vein diameter measurement: Portal vein diameter is measured where the portal vein crosses inferior vena cava anteriorly. ${ }^{4}$ In normal persons, the portal vein diameter does not exceed $13 \mathrm{~mm}$ in quiet respiration.

Upper GI endoscopy: It was done using video endoscope in Department of Gastroenterology, SCB Medical College, Cuttack and grading of oesophageal varices was done. ${ }^{5}$

Grade I- Small and straight varices.

Grade II- Tortuous and occupying less than one third of oesophageal lumen.

Grade III- Large and occupying more than one third of oesophageal lumen.

\section{Statistical Analysis}

The observed data was statistically analysed by using IBMcompatible Statistical Package for the Social Sciences (SPSS) version 20.0. The qualitative data were expressed as numbers $(\%)$, while the continuous quantitative data as mean \pm standard deviation (SD) and the comparisons of continuous variables between the two groups were performed with Student's t-test and categorical variables were compared using the Chi-square test. A p-value of $<0.05$ was considered significant and $\mathrm{p}$-value of $<0.001$ was considered highly significant, while $\mathrm{p}$-value of $>0.05$ was considered not significant.

\section{RESULTS}

Total 50 adult patients of cirrhosis of liver were included in the study, out of which $42(84 \%)$ were male and $8(16 \%)$ were female of ages between 20-70 years, mean $47.66 \pm$ 11.12 years. [Table-1 \& Table-2].

\begin{tabular}{|c|c|c|}
\hline Patients & Number & \% \\
\hline Male & 42 & 84 \\
\hline Female & 8 & 16 \\
\hline \multicolumn{2}{|c|}{ Table 1. Sex Distribution of Patients } \\
\hline
\end{tabular}

\begin{tabular}{|c|c|c|}
\hline Age & Patients & \% \\
\hline $20-30$ & 3 & 6 \\
\hline $31-40$ & 12 & 24 \\
\hline $41-50$ & 17 & 34 \\
\hline $51-60$ & 12 & 24 \\
\hline $61-70$ & 6 & 12 \\
\hline \multicolumn{2}{|c|}{ Table 2. Age Distribution of Patients } \\
\hline
\end{tabular}

Out of 50 patients, $34(68 \%)$ had oesophageal varices and $16(32 \%)$ had no varices at the time of presentation. No sex difference in presence of the oesophageal varix was detected. In our study, alcohol was commonest aetiology (72\%) followed by Hepatitis B virus infection (28\%) for cirrhosis of liver. Table-3.

\begin{tabular}{|c|c|c|}
\hline Aetiology & No. of Cases & \% \\
\hline Alcohol & 36 & 72 \\
\hline Hepatitis B & 14 & 28 \\
\hline Hepatitis C & 0 & 0 \\
\hline Metabolic cause & 0 & 0 \\
\hline \multicolumn{2}{|c|}{ Table 3. Aetiology of Cirrhosis } \\
\hline
\end{tabular}

Clinical features of patients with cirrhosis were anaemia (100\%), splenomegaly (74\%), jaundice (32\%) and hepatomegaly (24\%). Table-4.

\begin{tabular}{|c|c|c|}
\hline Clinical Features & Cases & $\mathbf{\%}$ \\
\hline Anaemia & 50 & 100 \\
\hline Splenomegaly & 37 & 74 \\
\hline Jaundice & 16 & 32 \\
\hline Hepatomegaly & 12 & 24 \\
\hline \multicolumn{2}{|c|}{ Table 4. Clinical Features of Patients } \\
\hline
\end{tabular}

Investigation shows average platelet count was markedly lower in patients with varices $(1,17,000 \pm 21,000) / \mathrm{mL}$ than in patients without varices $(1,70,000 \pm 30,000) / \mathrm{mL}, \mathrm{p}=0.001$. Average spleen size in variceal group was $(14.7 \pm 0.82) \mathrm{cm}$ and that of non-variceal group was $(12.2 \pm 1.01) \mathrm{cm}, \mathrm{p}=0.007$. Average portal vein diameter in variceal group was $13.46 \pm$ $0.98 \mathrm{~mm}$ and that of non-variceal group was $10.91 \pm 0.65$ $\mathrm{mm}, \mathrm{p}=0.03$. Table-5.

\begin{tabular}{|c|c|c|c|}
\hline Parameters & $\begin{array}{c}\text { Variceal Group } \\
(\mathbf{n}=34)\end{array}$ & $\begin{array}{c}\text { Non-Variceal } \\
\text { Group }(\mathbf{n}=16)\end{array}$ & P value \\
\hline $\begin{array}{c}\text { Haemoglobin } \\
\text { (g/dL) }\end{array}$ & $10.2 \pm 1.4$ & $10.6 \pm 1.2$ & $\mathrm{P}=0.18$ \\
\hline $\begin{array}{c}\text { T. Bilirubin } \\
\text { (mg/dL) }\end{array}$ & $5.3 \pm 2.1$ & $5.7 \pm 2.4$ & $\mathrm{P}=0.37$ \\
\hline $\begin{array}{c}\text { Platelet } \\
\text { count/mL }\end{array}$ & $\begin{array}{c}2,17,000 \pm \\
21,000\end{array}$ & $\begin{array}{c}1,70,000 \pm \\
30,000\end{array}$ & $\mathrm{P}=0.001$ \\
\hline $\begin{array}{c}\text { S. Albumin } \\
\text { (g/dL) }\end{array}$ & $2.64 \pm 0.31$ & $2.80 \pm 0.32$ & $\mathrm{P}=0.64$ \\
\hline INR & $1.80 \pm 0.42$ & $1.62 \pm 0.20$ & $\mathrm{P}=0.23$ \\
\hline $\begin{array}{c}\text { Spleen size } \\
\text { (cm) }\end{array}$ & $14.7 \pm 0.82$ & $12.2 \pm 1.01$ & $\mathrm{P}=0.007$ \\
\hline $\begin{array}{c}\text { PV diameter } \\
\text { (mm) }\end{array}$ & $13.46 \pm 0.98$ & $10.91 \pm 0.65$ & $\mathrm{P}=0.03$ \\
\hline \multicolumn{4}{|c|}{ Table 5. Parameters between Variceal and } \\
Non-variceal Groups
\end{tabular}




\section{DISCUSSION}

In the present study, 50 patients of cirrhosis of liver were included with $34 \%$ patients in the age group of 41-50 years. The age ranged from 20 to 70 years with a mean age of 47.66 \pm 11.12 years (Table-2). The male to female ratio was $4.2: 1$ (Table-1). This wide gender variation may be due to lesser prevalence of consumption of alcohol among females than males. In our study, the most common aetiology of cirrhosis was alcohol, $36(72 \%)$ cases, and HBV infection in 14 (28\%) cases (Table-3). General symptoms found in our cirrhotic patients were swelling of feet (90\%), loss of appetite $(76.6 \%)$, swelling of abdomen (74\%) and various bowel disorders. Common physical findings observed in our study were anaemia $(100 \%)$, ascites $(76 \%)$, splenomegaly $(74 \%)$ and hepatomegaly (24\%). (Table-4). The various factors contributed to anaemia are dilution (Peneiva et al, 1946), haemolysis (Jones et al 1955), occult blood loss from GI tract (Sheehy et al, 1960) and hypersplenism.

In our study, serum albumin level in patients with varices was $2.64 \pm 0.31$ and among non-variceal group was $2.80 \pm$ 0.10 (Table-5). No significant difference was found among both groups $(\mathrm{p}=0.64)$.

In our study, INR of patients with varices was $1.23-2.72$ and INR of patients without varices was $0.8-1.56, \mathrm{p}=0.053$ (Table-5). INR of patients with varices remain higher than patients without varices. (Gill et al). ${ }^{6}$

The mean platelet count in the group with varices was $117,000 \pm 21,000 / \mathrm{uL}$, while that of the group without oesophageal varices was $170,000 \pm 30,000 / \mathrm{uL}$, with $\mathrm{p}=0.001$ (Table-5). A similar finding was reported by Fook-Hong et $\mathrm{al}^{7}$ in 1999 with a mean value of platelet count $110,000 \pm$ $52,000 / \mathrm{mL}$ among those with oesophageal varices and $160,000 \pm 90,000 / \mathrm{mL}$ in the group without oesophageal varices, $p=0.011$. Thrombocytopenia in liver cirrhosis is due to changes in the microcirculation and hypersplenism related to portal hypertension as well as inadequate thrombopoietin synthesis in liver. In our study, 34 (68\%) patients had normal bilirubin (68\%) and $16(32 \%)$ had jaundice. AST level was more than ALT level in cirrhosis in our study. Progression of liver fibrosis may reduce the clearance of AST, leading to increased serum AST levels. In addition, advanced liver disease may be associated with mitochondrial injury, causing more release of AST, which is present in mitochondria and cytoplasm than ALT.

In our study, on ultrasound examination, cephalocaudal splenic measurement in the group with oesophageal varices was $14.7 \pm 0.82 \mathrm{~cm}$, while in the group without oesophageal varices the cephalocaudal splenic measurement was $12.2 \pm$ $1.01 \mathrm{~cm}, \mathrm{p}=0.007$ (Table-5). Fook- Hong et $\mathrm{al}^{7}$ in their study in Hong Kong found cephalocaudal splenic measurement of 11.7 $\pm 3.2 \mathrm{~cm}$ in the group with oesophageal varices, and $10.2 \pm$ $2.8 \mathrm{~cm}$ in the group without oesophageal varices.

Giannini et $\mathrm{al}^{8}$, in their study in Italy in 2003 , found a cutoff point of platelet count for presence of varices was $112,000, p=0.0001$ and splenic diameter $>12.1 \mathrm{~cm}, \mathrm{p}=0.0007$. Previous data from the Department of Hepatology of Cipto Mangunkusumo Hospital, Jakarta by Pridady 9 found an anteroposterior splenic measurement of $7.6 \pm 1.2 \mathrm{~cm}$ in normal subjects and $12.7 \pm 2.1 \mathrm{~cm}$ among patients with liver cirrhosis. Schepi et $\mathrm{al}^{10}$ in Italy found a mean anteroposterior splenic measurement of $16.3 \pm 2.7 \mathrm{~cm}$ in the group with oesophageal varices, and $13.9 \pm 2.5 \mathrm{~cm}$ in the group without oesophageal varices. This difference in splenic size may be due to racial, genetic, and anatomical differences.

In our study, the mean portal vein diameter in the group with oesophageal varices was $13.46 \pm 0.98 \mathrm{~mm}$, while that in the group without oesophageal varices was $10.91 \pm 0.65 \mathrm{~mm}$, $\mathrm{p}=0.03$ (Table-5).

Pridady ${ }^{9}$ found a mean portal vein diameter of $7 \pm 1 \mathrm{~mm}$ among normal subjects and $12 \pm 2 \mathrm{~mm}$ among cirrhotic patients. Fook-Hong et $\mathrm{al}^{7}$, in their study, found a portal vein diameter of $11.5 \pm 2.40 \mathrm{~mm}$ among patients with oesophageal varices, and $10.5 \pm 2.60 \mathrm{~mm}$ among patients without oesophageal varices. Schepis et $\mathrm{al}^{10}$ found a portal vein diameter of $13.82 \pm 2.1 \mathrm{~mm}$, among patients with oesophageal varices and $12.33 \pm 2.04 \mathrm{~mm}$ among patients without oesophageal varices. Prihatini et al ${ }^{11}$ concluded in their study that portal vein size $1.2-\mathrm{cm}$ ultrasound gives the evidence of presence of oesophageal varices. Plestina et $\mathrm{al}^{12}$ concluded in their study that portal vein size on ultrasound independently associated with varices.

In our study, oesophageal varices were found in 34 patients $(68 \%)$ out of 50 study population. Sixteen patients $(32 \%)$ had no oesophageal varices detected. Chalasani et $\mathrm{al}^{13}$ in their study found oesophageal varices in $70 \%$, while Zaman et $\mathrm{al}^{14}$ found $68 \%$. The prevalence of oesophageal varices in liver cirrhosis ranged around $50 \%$ and $80 \%$, similar to the findings in our study. The high prevalence of oesophageal varices on endoscopy is probably due to the delay in seeking treatment after signs and symptoms of portal hypertension have developed. Up to now, endoscopy is the gold standard modality to identify oesophageal varices. ${ }^{15}$

\section{CONCLUSION}

The non-invasive parameters that can be used to detect presence of oesophageal varices in liver cirrhosis are platelet count equal to or less than $117,000 / \mathrm{mL}$, portal vein diameter of $10.9 \mathrm{~mm}$ or more, and anteroposterior splenic diameter $12.2 \mathrm{~cm}$ or more. Hence, measurement of portal vein diameter and splenic size by USG is a non-invasive predictive indicator of development of oesophageal varices in cirrhosis of liver. Further studies are needed to determine the degree of oesophageal varices and obtain a cut-off point in the degree of oesophageal varices that requires prevention of oesophageal variceal bleeding.

\section{REFERENCES}

[1] Dib N, Konate A, Oberti F, et al. Non-invasive diagnosis of portal hypertension in cirrhosis. Application to the primary prevention of varices. Gastroenterol Clin Biol 2005;29(10):975-87.

[2] Mandal L, Mandal SK, Bandyopadhyay D, et al. Correlation of portal vein diameter and splenic size with gastro-oesophageal varices in cirrhosis of liver. JICAM 2011;12(4):266-70.

[3] Bruneton JN, Benozio M, Blery $M$, et al. Ultrasonography of the spleen. Springer Berlin Heidelberg 1988.

[4] Goyal AK, Pokharna DS, Sharma SK. Ultrasonic measurements of portal vasculature in diagnosis of portal hypertension. A controversial subject reviewed. J Ultrasound Med 1990;9(1):45-8. 
[5] Beppu K, Inokuchi K, Koyanagi N, et al. Prediction of variceal hemorrhage by esophageal endoscopy. Gastrointest Endosc 1981;27(4):213-8.

[6] Gill ML, Atiq M, Sattar S, et al. Non endoscopic parameters for the identification of esophageal varices in patients with chronic hepatitis. J Pak Med Assoc 2004;54(11):575-7.

[7] $\mathrm{Ng} \mathrm{FH}$, Wong SY, Loo CK, et al. Prediction of oesophagogastric varices in patients with liver cirrhosis. J Gastroenterol Hepatol 1999;14(8):785-90.

[8] Giannini E, Botta F, Borro P, et al. Platelet count/spleen diameter ratio: proposal and validation of a non-invasive parameter to predict the presence of oesophageal varices in patients with liver cirrhosis. Gut 2003;52(8):1200-5.

[9] Pridady. Ultrasonografi sirosis hati di RS Cipto Mangunkusumo. Tesis. Jakarta: Bagian Ilmu Penyakit Dalam FKUI, 1984.

[10] Schepis F, Cammà C, Niceforo $\mathrm{D}$, et al. Which patients with cirrhosis should undergo endoscopic screening for esophageal varices detection? Hepatology 2001;33(2):333-8.
[11] Prihatini J, Lesmana LA, Manan C, et al. Detection of esophageal varices in liver cirrhosis using noninvasive parameters. Acta Med Indones 2005;37(3):126-31.

[12] Plestina S, Pulanic R, Kralik M, et al. Color Doppler ultrasonography is reliable in assessing the risk of esophageal variceal bleeding in patients with liver cirrhosis. Wien Klin Wochenschr 2005;117(1920):711-7.

[13] Chalasani N, Imperiale TF, Ismail A, et al. Predictors of large esophageal varices in patients with cirrhosis. Am J Gastroenterology 1999;94(11):3285-91.

[14] Zaman A, Hapke R, Flora K, et al. Factors predicting the presence of esophageal or gastric varices in patients with advanced liver disease. Am J Gastroenterol 1999;94(11):3292-6.

[15] Spiegel BM, Esrailian E, Eisen G. The budget impact of endoscopic screening for esophageal varices in cirrhosis. Gastrointest Endosc 2007;66(4):679-92. 